\title{
LIST OF ZOOPHAGOUS ITONIDIDAE
}

By E. P. FeLt, Albany, N. Y.

The following records show that a considerable number of gall midges are predaceous and that this habit appears among widely separated groups. The list of 29 species is far from complete, since we have made no attempt to include therein, species which doubtless prey upon other gall midges, a habit typical of Lestodiplosis and probably other genera.

Table of Reared Species

Predator

Coccidomyia pennsylvanica

C. erii

Dentifibula cocci

Endaphis americana

Dicrodiplosis coccidarum

D. californica

D. antennata

Mycodiplosis pulvinariæ

$M$. insularis

M. acarivora

Aphidoletes marina

A. cucumeris

A. borealis

A. meridionalis

A. basalis

Diadiplosis cocci

Karschomyia cocci

Lobodiplosis coccidarum

Arthrocnodax abdominalis

A. occidentalis

A. carolina

A. apiphila

A. meridionalis

Lestodiplosis grassator

L. peruvina

Lestodiplosis species

Itonida aphidivora

Cecidomyia coccidarum

Cecidomyia species
Host

Lecanium on beech

Erium lichtensioides

Aspidiotus uvæ

Eriophyes on ash

Orthezia and Dactylopius

Pseudococcus

Phenacoccus

Pulvinaria

Tetranychus (red spider)

Red spider on lemon

Aphis gossypii

Aphis gossypii

Aphid on tulip leaves

Siphonophora liriodendri

Aphids on Tanacetum (tansy)

Saissetia nigra

Pseudococcus sacchari

Orthezia and Dactylopius

Red spider

Red spider

Red spider

Beehive infested by mites

Eriophyes

Phylloxera galls

Hemichionaspis minor

Aleyrodes

Aphis malifolix

Orthezia and Dactylopius

Cicada eggs

Summarizing the above we find that the scale insects or Coccidx are preyed upon by the following nine genera: Coccidomyia, 2 species; Dentifibula, 1 species; Dicrodiplosis, 3 species; Mycodiplosis, 1 species; Diadiplosis, 1 species; Karschomyia, 1 species; Lobodiplosis, 1 species; Lestodiplosis, 2 species, and Cecidomyia, 1 species.

The plantlice or Aphididæ are attacked by Aphidoletes, 5 species; Lestodiplosis, 1 species, and Itonida, 1 species, the first genus evidently displaying a marked partiality for the Aphididæ. 
Tetranychus or red spider is preyed upon by 4 species of Arthrocnodax and 1 of Mycodiplosis. It will be seen by referring to the above tabulation, that Arthrocnodax displays a marked partiality for the Acarina.

The plant mites or Eriophyidæ are preyed upon by 1 species of Endaphis and 1 of Arthrocnodax.

A species of gall midge, genus unknown, has been reared or was supposed to have been reared from the eggs of the periodical Cicada, Tibicen septemdecim.

It appears very probable from the above records, particularly in connection with the observations of Mr. E. A. MacGregor upon Arthrocnodax carolina, that the value of certain gall midges as natural enemies has been largely overlooked. There are probably a considerable number of other species, presumably mostly undescribed, which have similar habits.

\section{ON THE ORIGINAL HABITAT OF STOMOXYS CALCITRANS}

By F: MuIR, Taihoku, Japan

In his interesting article on the geographical distribution of the stable fly, ${ }^{1}$ Prof. C. T. Brues writes that "it is probably a native of the old world, most likely of central Europe," and, near the end, "It is probably native to the palæarctic region from whence it has followed man in his migrations to all parts of the world."

I am not able to follow Mr. Brues in these conclusions, and as they are of some importance in economic entomology, when endeavoring to discover parasites to control this pest, I would like to state my reasons for differing from an authority who has given this species a great deal of study.

In judging of the native habitat of a widely distributed insect like S. calcitrans, there are two points that I consider necessary to take into consideration: (1) the center of activity of the genus as indicated by the geographical distribution of the species of the genus; (2) the number and specialization of the natural enemies of the species under consideration, and its relative abundance in the different regions.

Turning to Brues' list of species of Stomoxys, and, if we leave out of consideration calcitrans, which is world wide, nebulosa, which is doubtful, and pallida, which is without given habitat, we have twentyeight species, all of which belong to the Oriental and Ethiopian regions. Nine are native to India and Ceylon, and two a little to the east; fourteen to the African mainland and three to neighboring islands.

${ }^{1}$ Jour. Econ. Ent., Vol. 6, No. 6, 1913, pp. 459-477. 